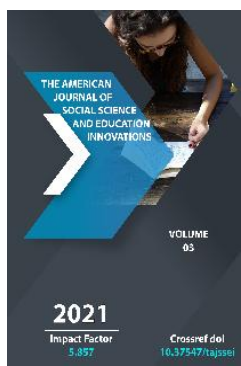

\title{
Turkic Dialects And Their Phenomena
}

\author{
Gulshoda Bakhtiarovna Allaberdieva \\ Lecturer, Department Of Teaching Languages, Fergana Polytechnic Institute, Uzbekistan \\ Matlyubakhon Anarjanovna Nazaralieva \\ Lecturer, Department Of Teaching Languages, Fergana Polytechnic Institute, Uzbekistan
}

Journal Website:

http://theamericanjour

nals.com/index.php/taj

ssei

Copyright: Original content from this work may be used under the terms of the creative commons attributes 4.0 licence.

\section{ABSTRACT}

This article devoted to theme about Turkic dialects and their phenomena. During the last century of the study and application of Turkic languages, the works of famous Turkologists have been used in scientific research, textbooks and manuals. Both the Turkic peoples and their languages have the most ancient history. It is given some examples in this article.

\section{KEYWORDS}

Dialects, scientific research, handwritten, origins and roots, tribal unions.

\section{INTRODUCTION}

Turkic nations and peoples are famous for their rich folklore and scientific knowledge of written monuments. It is known from history that the first written sources were found in Central Asia, Siberia and Mongolia under the name "Urhun-Enasay inscriptions". Works such as "Devonu lug'otit turk" and "Qutadg'u bilig" are also our common Turkic treasures.

In written sources it is possible to observe various riches, grammatical elements belonging to different dialects of Turkic languages. In particular, Mahmud Kashgari's "Devonu lugotit turk" stands out in this area. This, in turn, increases the importance of Devon in the study of dialects[2,6].

Therefore, it is important to compare dialect materials with the characteristics of these written sources. The materials of the textbook "Uzbek dialectology" are connected with the educational-scientific practice organized by 
the students of Samarkand State University in 1970 in Bakhmal district. More than 2 years have passed since then I have been studying dialects on a regular basis ever since. I listened to a lot of lectures on dialect materials, read scientific articles, compared some books.

Handwritten dialect materials form the basis of the book "Uzbek dialectology". The benefits of written memoirs in shaping the work more fully have been enormous. Because dialects and historical sources are similar and close to each other.

\section{MAIN PART}

The first written source is known as the Turkicrunic or Urhun-Enasay written monuments, Mahmud Kashgari's "Denonu lugotit turk", Yusuf Khos Khojib's "Kutadru bilig", from the last period to the time of Alisher Navoi[4,6]. Turkic written monuments, the universal heritage of our ancestor, valuable researches written by Abulgazi Bahodirkhan and, finally, all the sources specific to the later period are the main sources for studying, reading and researching the literature, languages and dialects of the Turkic peoples.

This means that both the Turkic peoples and their languages have the most ancient history. Today, Scythian-Turkic is spoken by more than 200 million people. It ranks second only to Chinese, Hindi, English, and Arabic. Accordingly, the influence of the ScythianTurkic language on other languages and their place in the vocabulary are significant.

Turkish words also make up a large part of the vocabulary of the Russian language written monuments such as the Annotated Dictionary of the Living Russian Language; Such excellent dictionaries as "Experiments from the study of Turkish dialects", "Dictionary of the Ruby
Language", "Dictionary of the Chuvash Language" also prove it.

Only one-tenth of the unique ancient written monuments in the Turkic languages have been discovered. This requires in-depth training in our universities as a special subject, as a specialization course and practice, to inculcate their essence in students, to prepare them for future researchers. To increase students' interest in historical written monuments; to accustom them to reading independently must be regarded as the sacred duty of every philologist, every turkologist.

\section{THE MAIN FINDINGS AND RESULTS}

During the last century of the study and application of Turkic languages, the works of famous Turkologists Abdurauf Fitrat, Ghazi Olim Yunusov, Mamed aga Sheraliev, Ulug Tursunov, Muhammad Isaev, Bozor Urinbaev have been used in scientific research, textbooks and manuals. Thus, the history, origins and roots of the Turkic peoples are common. This is evidenced by our ancient writings, written monuments, masterpieces of folklore[9,11].

For example, our Turkish brothers are proud of those who lived in the ancient Syrdarya oasis. They call Turkestan, the motherland of Uzbekistan. As they say their savior, mentor, and genius, Mustafa Aga, bequeathed to the his tombstone to write, "My homeland is Turkestan."

It is known that the Kipchak dialect of the Uzbek language is associated with such languages as Kazakh, Karakalpak, Kyrgyz, Tatar, while its Oghuz dialect has much in common with languages such as Turkmen, Azerbaijani and Turkish. 
The Qarluq-Chigil-Uyghur dialect is directly close to the Uyghur language. The chandirs, which form the basis of the Turkmen nation, also live in regions such as Kashkadarya and Samarkand. The bells are made up of Uzbeks and Crimean Tatars. Such evidence can be cited as desired.

Mahmud Kashgari's "Devonu lugotit turk" plays an important role in determining the historical development of the Turkic languages and in studying the languages of the tribes, clans and tribes of the past. He emphasizes this fact in his work: "Every tribe has innumerable seeds, from which I learned the basics, I dropped the branches."

Later, as a result of the tribes intermingling and merging with each other, their languages also became mixed and mixed.

The tribes would unite to defend themselves from an external enemy. In the subsequent stage of development of society, tribes and tribal alliances began to experience a process of mutual unification. As a result, their tongues became closer and closer to each other. During and after the ninth and tenth centuries, Central Asia was inhabited by Turkic-speaking sedentary and nomadic peoples. In particular, the population of the cities of Uzbekistan is mainly spoke Turkish. They were in constant contact with the nomadic Turkic and Iranian-speaking peoples (especially the Tajiks). In the IX-XI centuries the Uzbek people and language were formed on the basis of the Turkic-speaking people.

At a time when the Uzbeks were forming a nation, various Turkic and non-Turkic tribal alliances lived in a mixture. Therefore, in the formation of the Uzbeks as a people, in addition to the Turkic peoples of modern Uzbekistan, the Iranian people lived in the same economic conditions as the Turkic peoples, and fought together against external enemies. They embraced the traditions, culture and language of the Uzbeks and began to live together.

In other words, the Uzbekization of the Sogdians from the Iranian tribes, "the Uyghurs became an integral part of the Uzbeks, and their ethnographic unity has not been preserved.

There are number 510f Turkic languages. They are: Karakhanid-Uyghur language, KhorezmQarluq language, Mamluk-Kipchak language, Oghuz language of X-XI centuries, UrhunEnasay written language, Turkic language, Khorasan Turkic language, Chigatay language, Uyghur language, Yellow Uyghur language, ancient Uyghur language are given with the names of separate Turkic languages[10,12].

At present, it is not appropriate to separate them as separate languages of the Turkic peoples.

For example, there is no need to distinguish Uyghur from ancient Uyghur and KorahUyghur. Moreover, the use of "yellow Uyghur" is superfluous. All these are manifestations of the Uyghur language at different stages. It is not acceptable to say "Chigatoy language". Because there was no such language itself.

The emergence of the term "Chigatoy language" in the linguistic literature has become official since the publication of Kemam Vamberi's "Chigatay language textbook". This term I.Ilminsky and other turkologists are also used. It is also used in the dictionary of Sulayman Bukhari.

Rozi Olim Yunusov's study "An Experiment on the Classification of Uzbek Dialects" also 
mentioned 92 Uzbek tribes and their languages.

The fact that the numbers on the composition of our people and the dialects of the languages of each component are set at 92 is reflected in the various genealogies and in some recent details.

Twelve of the Turkic nations (Tatar, Kazakh, Kyrgyz, Bashkir, Karakalpak, Kumik, Crimean Tatar, Karachay, Balkar, Altai, Nogai, Karaim) are more than 15 million, and the Kipchak group consists of Turkic languages, too.

Eleven of the Turkic languages (Turkish, Azerbaijani, Turkmen, Afshar, Kashgar, Turkic peoples in southeastern Iran, Shahsevan, Gagauz, Karaparakh, Qadjar, Krimchak) belong to the Oghuz group of Turkic languages, which includes 37 million people. The 55 million Turks (Turkey) also belong to the Oghuz group.

5 nations (Uzbek, Uyghur, Salar, Yellow Uyghur, Khotan) are more than 15 million. These include the Qarluq group of Turkic languages. The Chuvash ( 1.7 million) are called the Bulgar group and the 8 nations (Ruby, Tuva, Khakas, Altai, Shur-Shor, Dulgan, Kuk Chulutan, Tofa-Karagas) are called the Siberian group (0.6 million).

Its history spans several tens of thousands of years. At that time, our ancestors lived in clans and tribes. Although in the XI-XII centuries, tribes and alliances of tribes united to form the Uzbek people, some of their features and appearance still remain.

This can be clearly seen in Alisher Navoi's "Muhokamatul Lughatain". One of such large tribal unions was called "Uzbek". This is especially the case. "Khazoinul maonii" in works such as "Saddi Iskandariy" is themed.
By 2020, the world's Turkic population could reach 240-250 million. If we talk about the common features of their languages, it should be noted that the stronger the cultural, educational, economic and commercial activities of the Turkic peoples, the more common and similar features of their languages. Because their origins go back to one source, this is a historical fact.

The study of literary language and dialects is strongly connected with the composition of vowels, both scientifically and practically. Only when all the branches of linguistics are interconnected their laws of development can be properly understood.

It is difficult to imagine such categories of possession in morphology, their variation, word formation, and in lexicon the study of the meanings of words, the identification of different district forms of words without taking into account the phonetic laws. This is especially important for dialects.

In order to perform such tasks, it is necessary to consider the following:

a) To determine the vowels used in pairs, to study them in two as the tone of the palate and the tone of the lips, to determine the relationship between them;

b) To determine the variability of melodic phenomena in historical periods, the extent of this law in the Uzbek dialects and, in this connection, the shortness of the number of vowel phonemes:

c) To indicate the presence or absence of primary vowels, ie long Turkic vowels, characteristic of some dialects of the Uzbek language, such as Karabulak, Ikon, Forish-Baghdad, South Khorezm, in the dialect under study;

d) To determine the ways of formation of secondary long vowels, resulting from the 
fall of certain phonemes, and the extent to which they are distributed between dialects;

e) Show the phonetic relationship associated with double vowels and their melodic properties;

f) To explain the possibility of the emergence of new phonemes, especially in the southern Khorezm and some Kipchak dialects, ie to determine whether such vowels appeared on the basis of this dialect material under the influence of the Uzbek literary language in the process of historical phonetic development of vowels;

g) To solve the reasons why some consonants, for example, in many dialects of the city and its suburbs, the phoneme $r$ is not used in pronunciation:

h) To determine the extent to which adjacent consonants affect the tendency of this or that vowel to lip and not to lip.

The famous linguist $\mathrm{V} . \mathrm{V}$. Reshetov devoted his dissertation to the Margilan dialect of the Uzbek language and his doctoral dissertation to the Qurama dialect of the Tashkent region.

Consider the use of phonemes in Jizzakh dialect words in the following words:

In Samarkand dialect: In Jizzakh dialect:

$\begin{array}{lc}\text { ман } & \text { мун } \\ \text { сан } & \text { сэн } \\ \text { дада } & \text { эта }\end{array}$

This phoneme is more widely used in the dialects of the Kipchak group than in the dialects of the Qarluq-Chigil-Uyghur group. Because the phoneme e replaces not only the phoneme $\mathrm{a}$ in the spelling, but also the phoneme o: ey g, ependi, kedir, nezik, chey, chech, chemeden, beyle, erdek, selim, kerim, mevlzi (эпэнди, кэдир, нэзик, чэй, чэч, чэмэдэн, бэйлэ, эрдэк, сэлим, кэрим, мэвлзи).

The reason for the frequent use of the phoneme e is that the phonemes a and o ch. It occurs through the influence of certain consonant sounds, such as j, y, x, g: jugeri, enekey, bejerdz, hasen tense, real (жугэри, энэкэй, бэжэрдз, хэсэн. гэримсэл, гэртэк).

Common Turkic words are used in most Turkic languages and dialects, and they can retain their pronunciation in Uzbek dialects or undergo strong and weak phonetic changes. This includes words related to land / jer, ish / is, bash / bas and many other areas. A significant part of the dialect dictionary consists of common Turkish words[3,8].

Words borrowed from Arabic, Persian, Tajik and Russian are used in dialects, mainly with phonetic simplification. The results of research show that in the dialect of dialect there are more Persian-Tajik words, Arabic words are less than it, Russian-international words are very rare shows that the process of weeding is more time consuming.

\section{CONCLUSION}

In short, the recording and extensive analysis of materials on Turkish dialectology is still carried out on a large scale. The teams of higher educational institutions of the Republic of Uzbekistan are working hard in this area. The fact that the Turkic nations and peoples are famous for their rich folklore and the scientific value of their written monuments also shows that these nations have a rich history[1,5]. 
Turkic dialects can still be the subject of research, that is, now all the issues of Uzbek dialects should be studied in terms of theoretical problems: phonology of Uzbek dialects, Turkish dialectology, etymology, comparative with Turkic languages. The study of such issues will serve to further enrich the Uzbek linguistics. The language of fiction is a reworked version of the richness of the language of the people. In this process, it is recognized that the masters of the art of speech refer to the dialect in which the story or the adventures of the protagonist take place. There is a concept of local coloring in the literature. This allows the writer to make extensive use of dialectal features in the expression of local experiences.

\section{REFERENCES}

1. Abdullaev F. A. The nature of the Chuzshu flours is correct. -UTAM, issue 3 . Tashkent, 1959.

2. Abdullaev F. A. Uzbek tilshshng Khorezm dialects. - Tashkent, Publishing House of the Academy of Sciences of the USSR, 1961.

3. Abdullaev F. A. Khorezm dialects of the Uzbek language. - Tashkent Publishing House of the Academy of Sciences of the USSR, 1964.

4. Abdullaev F. A. The Uzbek Literary Language and the Years of Its Development * -Uzbek Language and Literature, Issue 3, Tashkent. 1965.

5. Abdurakhmonov R., Rustamov A. K, adnmgi turkny til, —Tashkent, «Uk ituvchi, 1982.

6. Aliev A. - Materials from Uzbek dialectology. II. Tashkent, Publishing House of the Academy of Sciences of the USSR, 1961.

7. Aliev A. Yu, "Qutadgu bilnge" and "Devonu lugotnt turk"- UTA, Issue 5, Tashkent.1970.
8. Aliev A. K. Namangan group dialects.UTA, issue 5 ,. Tashkent, 1969.

9. Axmedev N. Ways to correct dialectal errors. - Tashkeyt, 1988.

10. Jumanazarov Yu. Uzbek literary language and South Khorezm shapalark. Tashkent, 1971.

11. Mirzaev M., Usmovov S., Rasulov I., Web language. - Tashkent, Higher and Secondary School, 1968.

12. Mirzaev M. Bukhara dialects of the Uzbek language. - Tashkent, Fan, J969.

13. Mirzaev N. Ethnographic lexicon of the Uzbek language, A K D. - Tashkent, 1971.

14. Abdurakhmonova, M. M., ugli Mirzayev, M. A., Karimov, U. U., \& Karimova, G. Y. (2021). Information Culture And Ethical Education In The Globalization Century. The American Journal of Social Science and Education Innovations, 3(03), 384-388.

15. Karimov, U., \& Kasimov, I. (2018). THE IMPORTANCE OF MODERN INFORMATION TECHNOLOGIES IN DEVELOPMENT OF DISTANCE EDUCATION. In Перспективные информационные технологии (ПИТ 2018) (pp. 1186-1187).

16. Karimov, U., \& Abdurakhmon, A. (2017). INNOVATIVE INFORMATION TECHNOLOGY IN EDUCATION. Форум молодых ученых, (5), 9-12.

17. Abdupattoev M. T. Unusual Connections As Forming Literary Text //The American Journal of Social Science and Education Innovations. - 2021. - T. 3. - №. 02. - C. 177182.

18. Kuzibaevna, O. G. (2020). TECHNOLOGIES OF DEVELOPING THE ECOLOGICAL CULTURE OF STUDENTS IN THE PROCESS OF LEARNING A FOREIGN LANGUAGES IN HIGHER EDUCATIONAL INSTITUTIONS. Solid State Technology, 63(1s), 1816-1825. 